\section{NOTE}

\title{
Correction to the authority of Rhizobium leguminosarum
}

\author{
J. M. Young \\ Tel: +649815 4200. Fax: +649849 7093.e-mail: youngj@landcare.cri.nz
}

Landcare Research,

Private Bag 92170,

Auckland, New Zealand
Keywords: Rhizobium leguminosarum
The origins of the epithet Rhizobium leguminosarum are obscure. Early interpretations of the authority were Frank 1890 [Landwirtschäftliche Jahrbücher 19 (1890), 563] emend. Baldwin and Fred 1929 [Journal of Bacteriology 17 (1929), 146] as reported in editions of Bergey's Manuals of Determinative Bacteriology up to the 7th edition (Breed et al., 1957). The presently accepted authority for Rhizobium leguminosarum is (Frank 1879) Frank 1889, 338 ${ }^{\mathrm{AL}}$ (Schinzia leguminosarum Frank 1879, 397), first cited by Buchanan et al. (1966), who correctly gave the publication of Frank (1879) as Botanische Zeitung 37 (1879), 376-387, 394-399. However, Jordan \& Allen (1974) incorrectly gave this reference as Berichte der Deutschen Botanischen Gesellschaft 37 (1879), 376-387, 394-399. This error has been repeated by Jordan (1984) and in the original and amended editions of the Approved Lists (Skerman et al., 1980, 1989). It is proposed that a correction be made in the next edition of the Approved Lists.

\section{References}

Breed, R. S., Murray, E. G. D. \& Smith, N. R. (editors) (1957).
Bergey's Manual of Determinative Bacteriology, 7th edn. Baltimore: Williams \& Wilkins.

Buchanan, R. E., Holt, J. G. \& Lessel, E. F. (1966). Index Bergeyana. Baltimore: Williams \& Wilkins.

Frank, B. (1879). Ueber die Parasiten in den Wurzelanschwillungen der Papilionaceen. Bot Ztg 37, 376-387, 394-399.

Frank, B. (1889). Ueber die Pilzsymbiose der Leguminosen. Ber Deut Bot Ges 7, 332-346.

Jordan, D. C. (1984). Family III. Rhizobiaceae Conn 1938, $321^{\mathrm{AL}}$. In Bergey's Manual of Systematic Bacteriology, vol. 1, pp. 234-256. Edited by N. R. Krieg \& J. G. Holt. Baltimore: Williams \& Wilkins.

Jordan, D. C. \& Allen, O. N. (1974). Family III. Rhizobiaceae Conn 1938, 321. In Bergey's Manual of Determinative Bacteriology, vol. 1, pp. 261--267. Edited by R. E. Buchanan \& N. E. Gibbons. Baltimore: Williams \& Wilkins.

Skerman, V. B. D., McGowan, V. \& Sneath, P. H. A. (1980). Approved lists of bacterial names. Int $J$ Syst Bacteriol 30 , 225-420.

Skerman, V. B. D., McGowan, V. \& Sneath, P. H. A. (editors). (1989). Approved Lists of Bacterial Names. Washington, DC: American Society for Microbiology. 